\title{
Erratum to: Guidewire advancement is interrupted by an internal jugular vein valve with a restricted opening: an ultrasound image
}

\author{
Takahiro Tadokoro, MD • Kouji Yoza, PhD • \\ Kazuhiro Sugahara, MD, PhD
}

Published online: 18 December 2013

(C) Canadian Anesthesiologists' Society 2013

\section{Erratum to: Can J Anesth/J Can Anesth (2013) \\ 60:1163-1164 \\ DOI 10.1007/s12630-013-0022-8}

In the article entitled: "Guidewire advancement is interrupted by an internal jugular vein valve with a restricted opening: an ultrasound image" published in the November 2013 issue, Can J Anesth 2013; DOI: 10.1007/ s12630-013-0022-8, references \#1, \#4 and \#5 should read:

1. Macchi $C$, Catini $C$. The valves of the internal jugular veins: a statistical investigation in 120 living subjects using ultrasonic tomography. Ital $\mathrm{J}$ Anat Embryol 1994; 99: 123-7.

4. Sander D, Winbeck K, Etgen T, Knapp R, Klingelhofer $J$, Conrad B. Disturbance of venous flow patterns in patients with transient global amnesia. Lancet 2000; 356: 1982-4.

5. Boes CJ, Matharu MS, Goadsby PJ. Benign cough headache. Cephalalgia 2002; 22: 772-9.

The publisher apologizes most sincerely for this error.

The online version of the original article can be found under doi:10.1007/s12630-013-0022-8.

T. Tadokoro, MD $(\bowtie) \cdot$ K. Yoza, PhD

Department of Anesthesiology, Okinawa Prefectural Nanbu

Medical Center \& Children's Medical Center, Okinawa, Japan

e-mail: rover2727@yahoo.co.jp

K. Sugahara, MD, $\mathrm{PhD}$

Department of Anesthesiology, Faculty of Medicine, University

of the Ryukyus, Okinawa, Japan 